\title{
技術報告
}

\section{原子吸光法による鉄鉱石中の微量成分定量方法における 試料分解法の比較}

\author{
大 柣 孝* \\ (1978 年 9 月 14 日受理)
}

\begin{abstract}
鉄鉱石中のマンガン, 銅, 酸化チタン, ニッケル, クロム, バナジウム, 亜鉛及び鉛を酸分解一原子 吸光法（JIS M 8204/1971）とアルカリ融解一原子吸光法の 2 方法で社内 10 分析室間の共同実験を行 って試料分解方法間の分析精度，正確さを比較し，更に検出下限及び定量下限について論じた. その結 果, 酸分解法は, 酸化チタン及びバナジウムの定量用試料溶液の塩酸濃度を上げる必要があるが全般に 好結果を示した．とれに対してアルカリ融解法は，銅及び鉛が白金るつぼと合金を生成して損失し低 值を与えたが，その他の成分については酸分解法と同程度の精度及び正確さを示した.なお，JIS M 8204-1971 に示されている適用下限值における分析精度は偏差率として 30\% 以上であり，この実験結 果から求めた検出下限に近似する值であった。
\end{abstract}

\section{1 まえがき}

購入原料の検収上, 及び高炉操業管理上鉄鈗石中の微 量成分を分析する必要がある。その際, 鉄鉱石中のマン ガン，銅，酸化チタン，ニッケル，クロム，バナジウ 么, 亚鉛及び鉛などの微量成分は, 原子吸光分析法で定 量するのには最も適した成分である.しかし，これらを JIS M 8204-1971 法で定量しようとすると，試料を酸 分解した後, 残さ処理をして主液に合する操作が必要で あり, 省力化が要求されている現在, 一考を要する点と なっている.そこで当社では, 陚料を直接アルカリ融解 して共通母液を調製し，原子吸光分析法で連けい定量を 行らことによって省力化を図ることにし，共同実験によ ってその妥当性を確かめることにした，以下，その結果 をとりまとめて報告する。

\section{2 尖験装解}

\section{1 加分析所}

社内 10 分析室（8 製鉄所と 2 研究等の分析窒）がこ の共同実験に参加して, 著者に扣いて共通試料の配布, 分析方法及び実験の指示, データの収集, 解析並びに考 察を行った.

* 新日本製鉄 (株) 基礎研究所：神奈川県川崎市中原区 井田 1618

\section{$2 \cdot 2$ 共通試料}

実験に供した共通試料は，Table 1 に示す組成を持っ た鉄鈗石試料 11 銘柄（普通鉄鉱石 8 , 砂鉄 1 , ペレッ ト1及び焼結鉱 1) で，そのうち8 銘柄は日本鉄鋼標準 試料（JSS）で，残り 3 銘柄はこの実験用に社内で特別 に調製した試料である.

これらの試料は，必要量を縮分して銘柄名を伏せ，一 般的な鈗種名で各分析室に配布した.

各分析室では，配布された試料を空気浴中で（105〜 $110)^{\circ} \mathrm{G}$ に 2 時間保持し，デシヶーター中で常温まで冷 却した後, 分析に供した.

\section{3 分析方法}

比較するために指示した分析方法は, 試料を酸分解し た後，残さ処理をして主液に合する方法（以下，酸分解 法と呼ぶ）と，試料を直接アルカリ融解して塩酸溶液と する方法（以下，アルカリ融解法と呼ぶ）の 2 万法であ る.

2.3.1 酸分解法 この方法は, JIS M 8204-1971 （鉄鉱石の原子吸光分析法）によっており，定量操作は 次のと呿りである.

（1）マンガン，銅，ニッケル，クロム，亜鉛及び鉛 の定量

i ) 試料 $1.000 \mathrm{~g}$ を塩酸 $30 \mathrm{ml}$ に加熱分解し, 少量 
Table 1 Ghemical compositions of iron ore samples used for round robin test

\begin{tabular}{|c|c|c|c|c|c|c|c|c|c|c|c|c|c|c|c|}
\hline \multirow{2}{*}{\multicolumn{2}{|c|}{ Brand }} & \multicolumn{14}{|c|}{ Contents (\%) } \\
\hline & & \multirow{2}{*}{$\begin{array}{l}\text { T. Fe } \\
62.85\end{array}$} & \multirow{2}{*}{$\frac{\mathrm{SiO}_{2}}{2.60}$} & \multirow{2}{*}{$\frac{\mathrm{Al}_{2} \mathrm{O}_{3}}{2.01}$} & \multirow{2}{*}{$\begin{array}{l}\mathrm{CaO} \\
0.02\end{array}$} & \multirow{2}{*}{$\begin{array}{r}\mathrm{MgO} \\
0.22\end{array}$} & \multirow{2}{*}{$\frac{\mathrm{M}_{\mathrm{n}}}{0.22}$} & \multirow{2}{*}{$\frac{\mathrm{Cu}}{0.065}$} & \multirow{2}{*}{$\begin{array}{r}\mathrm{TiO}_{2} \\
0.08\end{array}$} & \multirow{2}{*}{$\frac{\mathrm{Ni}}{-}$} & \multirow{2}{*}{$\begin{array}{c}\mathrm{Cr} \\
-\end{array}$} & \multirow{2}{*}{$\frac{V}{0.006}$} & \multirow{2}{*}{$\frac{\mathrm{Zn}}{0.103}$} & \multirow{2}{*}{$\frac{\mathrm{Pb}}{0.022}$} & \multirow{2}{*}{$\frac{\mathrm{Bi}}{0.023}$} \\
\hline Rompin & JSS 800-3 & & & & & & & & & & & & & & \\
\hline Indian & JSS $801-3$ & 64.68 & 2.13 & 2.61 & 0.03 & 0.02 & 0.06 & $(0.003)$ & 0.16 & - & 0.012 & 0.008 & - & - & - \\
\hline Harmersley & JSS 803-2 & 62.61 & 5.23 & 2.85 & 0.04 & 0.04 & 0.09 & $(0.001)$ & 0.12 & $(0.003)$ & $(0.004)$ & $(0.003)$ & $(0.003)$ & - & - \\
\hline Musan & JSS $812-2$ & 60.19 & 14.35 & 0.40 & 0.64 & 0.46 & 0.03 & $(0.001)$ & 0.06 & $(0.002)$ & $(0.004)$ & 0.003 & - & - & - \\
\hline Algarrobo & JSS 813-1 & 61.15 & 6.58 & 1.27 & 1.21 & 1.07 & 0.05 & 0.012 & 0.22 & 0.008 & $(0.003)$ & 0.16 & - & - & - \\
\hline $\begin{array}{l}\text { Philippine } \\
\text { (Iron sand) }\end{array}$ & JSS $830-3$ & 60.57 & 2.26 & 2.75 & 0.68 & 2.15 & 0.61 & 0.011 & 6.33 & $(0.006)$ & 0.018 & 0.30 & 0.075 & - & - \\
\hline $\begin{array}{l}\text { Marcona } \\
\text { (Pellet) }\end{array}$ & JSS $850-3$ & 66.78 & 2.56 & 0.49 & 0.37 & 0.73 & 0.04 & 0.015 & 0.08 & $(0.006)$ & $(0.002)$ & 0.049 & 0.021 & - & - \\
\hline Sintered ore & JSS $851-2$ & 57.25 & 5.12 & 2.23 & 9.34 & 0.68 & 0.51 & 0.018 & 0.62 & 0.012 & 0.023 & 0.040 & 0.058 & - & - \\
\hline Chaugle & & & $(3.00)$ & $(2.83)$ & $(0.03)$ & $(0.06)$ & & & & & & & & & \\
\hline Dempo & & & $(2.15)$ & $(1.61)$ & $(0.02)$ & $(0.07)$ & & & & & & & & & \\
\hline Mt. Newman & & & $(6.15)$ & $(2.82)$ & $(0.04)$ & $(0.05)$ & & & & & & & & & \\
\hline
\end{tabular}

( ) Non-standardized value

の硝酸で鉄などを酸化してほとんど乾固するまで加熱を 続ける. 更に塩酸 $10 \mathrm{ml}$ を加え，加熱して乾固する.

ii ) 冷却後, 可溶性塩類を塩酸 $(1+1) 20 \mathrm{ml}$ に加熱し て溶解し，不溶解残さをろ紙 ( 5 種 B ) と少量のろ紙パル プでろ過して温塩酸 $(2+100)$ と温水で十分に洗浄する. ろ洗液は合わせて加熱濃縮し, 主液として保存する。

iii）不溶解残さは，万紙とともに白金るつぼ中で乾燥 後強熱灰化する. 冷却後, 残さを硫酸 $(1+1)$ とフッ化 水素酸で二酸化ヶイ素を揮散させる. 冷却後ピロ硫酸力 リウム $1.0 \mathrm{~g}$ を加えて加熱融解する. 冷却後融成物を 主液と少量の塩酸に加熱溶解する.

iv）この溶液を加熱して約 $50 \mathrm{ml}$ まで濃縮し，冷却 後 $100 \mathrm{ml}$ のメスフラスコに移し入れて水で標線までら すめる．この溶液を $\mathrm{A}$ 溶液とする.

A 溶液 $10 \mathrm{ml}$ を分取して $100 \mathrm{ml}$ のメスフラスコに移 し入れ，塩酸 $(1+1) 30 \mathrm{ml}$ 及びストロンチウム溶液 $(20 \mathrm{mg} \mathrm{Sr} / \mathrm{ml}) 10 \mathrm{ml}$ を加えて水で標線までうすめる. この溶液を B 溶液とする.

v ）原子吸光光度計を用いてフレーム中にA溶液及び B 溶液を噴霧し，目的元素の分析線に括ける吸光度を測 定する。このとき A 溶液からは，銅，ニッケル，クロ ム，亜鉛及び鉛を， B 溶液からは，マンガンを定量す る.

(2) 酸化-タン及びバナジウムの定量

i ）試料の分解及び残さ処理は，2.3.1（1） i ）～iii) に従ら。

ii）この溶液を加熱して約 $50 \mathrm{ml}$ まで濃縮し，冷却 後 $100 \mathrm{ml}$ のメスフラスコに移し入れ，アルミニウム溶 液 $(5 \mathrm{mg} \mathrm{Al} / \mathrm{ml}) 10 \mathrm{ml}$ を加えて水で標線までうすめ る.

iii）原子吸光光度計を用いてフレーム中に試料溶液を
噴霧し，目的元素の分析線に和ける吸光度を測定する.

2.3.2 アルカリ虽解法 この方法の要旨は, 試料を 白金るつぼ中で無水ホウ酸ナトリウムと無水炭酸ナトリ ウムの等量混合物に融解した後, 塩酸に溶解して試料溶 液を調製し，原子吸光法で定量することである．定量操 作は次のと和りである.

（1） マンガン，銅，ニッケル，クロム，亜鉛及び鉛 の定量

i ) 試料 $1.000 \mathrm{~g}$ を量り取って融解合剤(住1) $3.0 \mathrm{~g}$ を入れた白金るつぼ（30 番）中に移し入れてよくかき 混ぜる。るつぼにふたをして初めは低温で加熱して内容 物を融解してからしだいに温度を高めて（1000～1100) ${ }^{\circ} \mathrm{G}$ とし，(20〜30) 分間(注2) 以上その温度に保ち, 完 全に融解する.

ii）るつぼを放冷した後, 塩酸 $(1+2) 50 \mathrm{ml}$ を入れ たビーカー $(200 \mathrm{ml})$ に入れ，静かに加熱して融成物を 溶解し，るつぼは水で洗って取り出す.

iii）冷却後, $100 \mathrm{ml}$ のメスフラスコに移し入れて水 で標線までうすめる。この溶液を $\mathrm{G}$ 溶液とする(注 3 ).

C 溶液 $20 \mathrm{ml}$ を分取して $100 \mathrm{ml}$ のメスフラスコに移 し入れて塩酸 $(1+2) 20 \mathrm{ml}$ 及びストロンチウム溶液 $(20 \mathrm{mg} \mathrm{Sr} / \mathrm{ml}) 20 \mathrm{ml}$ を加光, 水で標線までうすめる. この溶液をD溶液とする。

iv）原子吸光光度計を用いてフレーム中に C 溶液及び D溶液を噴霧し, 目的元素の分析線に括ける吸光度を測 定する。このとき $\mathrm{C}$ 溶液からは，銅，ニッケル，クロ ム，亜鉛及び鉛を，D溶液からは，マンガンを定量す る(注6).

(2) 酸化チタン及びバナジウムの定量

i ）試料の融解及び融成物の溶解は，2.3.2 (1) i ), ii) による. 


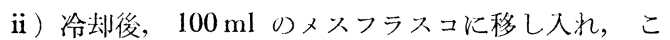
れにアルミニウム溶液 $(5 \mathrm{mg} \mathrm{Al} / \mathrm{ml}) 10 \mathrm{ml}$ を加えて 水で標線までうすめる(注 4,5 ).

iii）原子吸光光度部を用いてフレーム中に仼料溶液

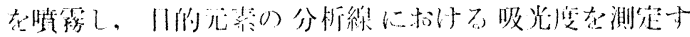
只(作( 6 ).

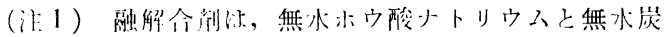
酸ナトリりムの管最混合物を用いる。

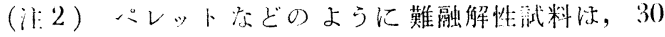
分間以上问温に保狩して完全に融解与る.

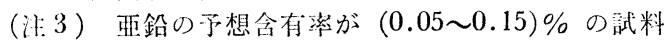
では，G 溶液 $20 \mathrm{ml}$ を分取し，塩酸 $(1+2)$ $20 \mathrm{ml}$ とともに $100 \mathrm{ml}$ のメスフラスコに入れ て水で標線までうすめる。

（注 4) 酸化チタンの予想含有率が (1〜7)\%の試料 では, この溶液 $10 \mathrm{ml}$ を分取し, 塩酸 $(1+2)$ $45 \mathrm{ml}$ とてルミニウム溶液 $(5 \mathrm{mg} \mathrm{Al} / \mathrm{ml}) 9 \mathrm{ml}$ とともに $100 \mathrm{ml}$ のメスフラスコに移して水で 標線までうすめる。
（注 5 ） バナジウムの尓想含有率が $(0.1 \sim 0.3) \%$ の 試料では，この溶液 $20 \mathrm{ml}$ を分取し，塩酸 (1 +2) $40 \mathrm{ml}$ とアルミニウム溶液 $(5 \mathrm{mg} \mathrm{Al} / 100$ ml) $8 \mathrm{ml}$ とともに $100 \mathrm{ml}$ のメスフラスコに 移し入れて水で標線までうすめる.

（注:6）検量線作成用の溶液は，酸化鉄（JSS802-2） 在処理して塩酸溶液とし, 目的元素の標準溶液 と必装に応じてストロンチウム溶液 $(20 \mathrm{mgSr} /$ $\mathrm{ml})$ あるいはテルミニウム溶液 $(5 \mathrm{mg} \mathrm{Nl} / \mathrm{ml})$ 芯抈えて调製する。

\section{4 実 験}

この実験を行らに当たっては, 参加分析室の担当分析 者が同程度の分析技能を持つ必要がある. 酸分解法につ いては JIS 法であるため, 改めて習熟のための実験は 行わなかったが，アルカリ融解法については, 一部の分 析室が未経験であったので，共通試料以外の試料を用い て予備的な実験を行い，習熟度を同一にした。

Table 2 Round robin test results of iron ores analysis by acid-attack A. A. S. method

\begin{tabular}{|c|c|c|c|c|c|c|c|c|c|c|c|c|}
\hline Element & & Rompin & Indian & Harmersley & Musan & Algarrobo & $\begin{array}{l}\text { Philippine } \\
\text { (Iron sand) }\end{array}$ & $\begin{array}{l}\text { Marcona } \\
\text { (Pellet) }\end{array}$ & Sinter & Chaugle & Dempo & $\begin{array}{c}\text { Mt. } \\
\text { Newman }\end{array}$ \\
\hline $\mathrm{Mn}$ & $\begin{array}{l}\text { Certified value }(\%) \\
\text { Average }(\%) \\
\sigma_{\overline{\mathrm{x}}} \\
\sigma_{\mathrm{w}} \\
\text { C. V. } \\
\text { Difference }(\%)\end{array}$ & $\begin{array}{l}0.22 \\
0.22_{2} \\
0.01_{3} \\
0.00_{4} \\
5.9 \\
\pm 0.00\end{array}$ & $\begin{array}{l}0.06 \\
0.06_{2} \\
0.00_{3} \\
0.00_{2} \\
5.5 \\
\pm 0.00\end{array}$ & $\begin{array}{l}0.09 \\
0.08_{4} \\
0.00_{6} \\
0.00_{3} \\
7.5 \\
-0.01\end{array}$ & $\begin{array}{l}0.03 \\
0.03_{2} \\
0.00_{3} \\
0.00_{2} \\
9.5 \\
\pm 0.00\end{array}$ & $\begin{array}{l}0.05 \\
0.05_{2} \\
0.00_{3} \\
0.00_{2} \\
6.6 \\
\pm 0.00\end{array}$ & $\begin{array}{l}0.61 \\
0.60_{5} \\
0.01_{7} \\
0.00_{7} \\
2.8 \\
-0.01\end{array}$ & $\begin{array}{l}0.04 \\
0.03_{7} \\
0.00_{2} \\
0.00_{3} \\
6.5 \\
+0.00\end{array}$ & $\begin{array}{l}0.51 \\
0.50_{4} \\
0.01_{7} \\
0.00_{3} \\
3.4 \\
-0.01\end{array}$ & $\begin{array}{l}-\overline{4} 8_{4} \\
0.01_{7} \\
0.00_{8} \\
3.5 \\
-\end{array}$ & $\begin{array}{l}0.51_{0} \\
0.01_{3} \\
0.01_{0} \\
2.5 \\
-\end{array}$ & $\begin{array}{l}\overline{-} \overline{07}_{8} \\
0.00_{4} \\
0.00_{4} \\
5.5 \\
-\end{array}$ \\
\hline Cu & $\begin{array}{l}\text { Certified value }(\%) \\
\text { Average }(\%) \\
\sigma_{\bar{x}} \\
\sigma_{\mathrm{w}} \\
\text { C. V. } \\
\text { Difference }(\%)\end{array}$ & $\begin{array}{l}0.065 \\
0.063_{7} \\
0.001_{5} \\
0.000_{9} \\
2.4 \\
-0.001\end{array}$ & $\begin{array}{l}(0.003) \\
0.002_{7} \\
0.000_{9} \\
0.000_{4} \\
33.3 \\
-\end{array}$ & $\begin{array}{c}(0.001) \\
0.001_{5} \\
0.000_{4} \\
0.000_{1} \\
26.7 \\
-\end{array}$ & $\begin{array}{l}(0.001) \\
0.001_{3} \\
0.000_{4} \\
0.000_{1} \\
30.8 \\
-\end{array}$ & $\begin{array}{l}0.012 \\
0.012_{3} \\
0.000_{8} \\
0.000_{9} \\
6.5 \\
\pm 0.000\end{array}$ & $\begin{array}{l}0.011 \\
0.010_{5} \\
0.000_{7} \\
0.000_{7} \\
6.7 \\
-0.001\end{array}$ & $\begin{array}{l}0.015 \\
0.015_{4} \\
0.000_{7} \\
0.000_{2} \\
4.5 \\
\pm 0.000\end{array}$ & $\begin{array}{l}0.018 \\
0.017_{6} \\
0.000_{5} \\
0.000_{5} \\
2.8 \\
\pm 0.000\end{array}$ & $\begin{array}{l}-\overline{0017} \\
0.000_{4} \\
0.000_{2} \\
23.5 \\
-\end{array}$ & $\begin{array}{l}-\overline{0.002_{0}} \\
0.000_{4} \\
0.000_{3} \\
20.0 \\
-\end{array}$ & $\begin{array}{l}\overline{0.001_{1}} \\
0.000_{3} \\
0.000_{1} \\
27.3 \\
-\end{array}$ \\
\hline $\mathrm{TiO}_{2}$ & $\begin{array}{l}\text { Certified value }(\%) \\
\text { Average }(\%) \\
\sigma \overline{\mathrm{x}} \\
\sigma_{\mathrm{w}} \\
\text { C. V. } \\
\text { Difference }(\%)\end{array}$ & $\begin{array}{l}0.08 \\
0.08_{0} \\
0.00_{9} \\
0.00_{7} \\
11.4 \\
\pm 0.00\end{array}$ & $\begin{array}{l}0.16 \\
0.15_{8} \\
0.01_{0} \\
0.00_{6} \\
6.3 \\
\pm 0.00\end{array}$ & $\begin{array}{l}0.12 \\
0.12_{4} \\
0.00_{9} \\
0.00_{9} \\
7.3 \\
\pm 0.00\end{array}$ & $\begin{array}{l}0.06 \\
0.05_{7} \\
0.00_{4} \\
0.00_{6} \\
7.3 \\
\pm 0.00\end{array}$ & $\begin{array}{l}0.22 \\
0.21_{7} \\
0.01_{1} \\
0.00_{5} \\
5.1 \\
\pm 0.00\end{array}$ & $\begin{array}{l}6.33 \\
6.27 \\
0.05_{7} \\
0.06_{4} \\
0.9 \\
-0.06\end{array}$ & $\begin{array}{c}0.08 \\
0.06_{8} \\
0.00_{8} \\
0.00_{2} \\
11.3 \\
-0.01\end{array}$ & $\begin{array}{l}0.62 \\
0.57_{8} \\
0.03_{9} \\
0.01_{5} \\
6.7 \\
-0.04\end{array}$ & $\begin{array}{l}-\overline{10} \\
0.10_{4} \\
0.00_{9} \\
0.00_{3} \\
8.7 \\
-\end{array}$ & $\begin{array}{l}-\overline{0.07_{5}} \\
0.01_{0} \\
0.00_{5} \\
12.7 \\
-\end{array}$ & $\begin{array}{l}-\overline{1} 1_{0} \\
0.00_{9} \\
0.00_{4} \\
8.2 \\
-\end{array}$ \\
\hline $\mathrm{Ni}$ & $\left\{\begin{array}{l}\text { Certified value (\%) } \\
\text { Average }(\%) \\
\sigma_{\overline{\mathbf{x}}} \\
\sigma_{\mathrm{w}} \\
\text { C. V. } \\
\text { Difference }(\%)\end{array}\right.$ & $\begin{array}{l}-\overline{0.002_{3}} \\
0.001_{8} \\
0.000_{4} \\
77.2 \\
-\end{array}$ & $\begin{array}{l}-\overline{0.004_{5}} \\
0.001_{5} \\
0.000_{5} \\
33.8 \\
-\end{array}$ & $\begin{array}{c}(0.003) \\
0.002_{4} \\
0.001_{4} \\
0.000_{3} \\
58.8 \\
-\end{array}$ & $\begin{array}{l}(0.002) \\
0.002_{5} \\
0.000_{9} \\
0.000_{4} \\
35.0 \\
-\end{array}$ & $\begin{array}{l}0.008 \\
0.007_{8} \\
0.002_{3} \\
0.000_{6} \\
29.6 \\
\pm 0.000\end{array}$ & $\begin{array}{c}(0.006) \\
0.005_{5} \\
0.002_{0} \\
0.000_{4} \\
36.6 \\
-\end{array}$ & $\begin{array}{l}(0.006) \\
0.006_{0} \\
0.001_{4} \\
0.000_{8} \\
23.5 \\
-\end{array}$ & $\begin{array}{l}0.012 \\
0.011_{2} \\
0.001_{4} \\
0.000_{6} \\
12.5 \\
-0.001\end{array}$ & $\begin{array}{l}\overline{0.002_{9}} \\
0.001_{2} \\
0.000_{2} \\
39.7 \\
-\end{array}$ & $\begin{array}{l}-\overline{0.003_{1}} \\
0.001_{2} \\
0.000_{5} \\
38.6 \\
-\end{array}$ & $\begin{array}{l}-\overline{0.002_{4}} \\
0.001_{0} \\
0.000_{3} \\
40.7 \\
-\end{array}$ \\
\hline $\mathrm{Cr}$ & $\left\{\begin{array}{l}\text { Certified value }(\%) \\
\text { Average }(\%) \\
\sigma_{\bar{x}} \\
\sigma_{\mathrm{w}} \\
\text { C. V. } \\
\text { Difference }(\%)\end{array}\right.$ & $\begin{array}{l}-\overline{0.0037} \\
0.000_{7} \\
0.000_{5} \\
18.4 \\
-\end{array}$ & $\begin{array}{c}0.012 \\
0.012_{4} \\
0.001_{4} \\
0.001_{1} \\
11.2 \\
\pm 0.000\end{array}$ & $\begin{array}{l}(0.004) \\
0.003_{7} \\
0.000_{5} \\
0.000_{4} \\
14.5 \\
-\end{array}$ & $\begin{array}{l}(0.004) \\
0.003_{6} \\
0.000_{3} \\
0.000_{4} \\
7.4 \\
-\end{array}$ & $\begin{array}{c}(0.003) \\
0.002_{5} \\
0.000_{6} \\
0.000_{4} \\
24.6 \\
-\end{array}$ & $\begin{array}{l}0.018 \\
0.017_{9} \\
0.001_{5} \\
0.000_{8} \\
8.4 \\
\pm 0.000\end{array}$ & $\begin{array}{l}(0.002) \\
0.001_{7} \\
0.000_{5} \\
0.000_{3} \\
28.0 \\
-\end{array}$ & $\begin{array}{l}0.023 \\
0.024_{6} \\
0.001_{5} \\
0.001_{2} \\
6.1 \\
+0.002\end{array}$ & $\begin{array}{l}\overline{0.003_{9}} \\
0.000_{6} \\
0.000_{3} \\
15.0 \\
-\end{array}$ & $\begin{array}{l}\overline{0.003_{3}} \\
0.000_{3} \\
0.000_{5} \\
8.7 \\
-\end{array}$ & $\begin{array}{l}-\overline{0004_{2}} \\
0.000_{4} \\
0.000_{4} \\
9.1 \\
-\end{array}$ \\
\hline V & $\left\{\begin{array}{l}\text { Certified value (\%) } \\
\text { Average }(\%) \\
\sigma \overline{\mathbf{x}} \\
\sigma_{\mathrm{w}} \\
\text { C. V. } \\
\text { Difference }(\%)\end{array}\right.$ & $\begin{array}{l}0.006 \\
0.005_{8} \\
0.001_{2} \\
0.000_{5} \\
21.4 \\
\pm 0.000\end{array}$ & $\begin{array}{l}0.008 \\
0.007_{6} \\
0.001_{0} \\
0.000_{8} \\
13.7 \\
\pm 0.000\end{array}$ & $\begin{array}{c}(0.003) \\
0.003_{5} \\
0.000_{5} \\
0.000_{3} \\
15.0 \\
-\end{array}$ & $\begin{array}{l}0.003 \\
0.003_{6} \\
0.000_{5} \\
0.000_{7} \\
13.6 \\
+0.001\end{array}$ & $\begin{array}{l}0.16 \\
0.16_{6} \\
0.00_{6} \\
0.00_{4} \\
3.6 \\
+0.01\end{array}$ & $\begin{array}{l}0.30 \\
0.30_{7} \\
0.029 \\
0.00_{7} \\
9.4 \\
+0.01\end{array}$ & $\begin{array}{l}0.049 \\
0.049_{5} \\
0.002_{3} \\
0.002_{8} \\
4.6 \\
+0.001\end{array}$ & $\begin{array}{l}0.040 \\
0.039_{8} \\
0.002_{5} \\
0.001_{6} \\
6.3 \\
\pm 0.000\end{array}$ & $\begin{array}{l}\overline{0.003_{4}} \\
0.000_{8} \\
0.000_{5} \\
25.3 \\
-\end{array}$ & $\begin{array}{l}-\overline{0.003_{2}} \\
0.000_{9} \\
0.000_{7} \\
27.6 \\
-\end{array}$ & $\begin{array}{l}-\overline{0.003_{1}} \\
0.001_{2} \\
0.000_{4} \\
37.3 \\
-\end{array}$ \\
\hline $\mathrm{Zn}$ & $\left\{\begin{array}{l}\text { Certified value }(\%) \\
\text { Average }(\%) \\
\sigma_{\overline{\mathrm{x}}} \\
\sigma_{\mathrm{w}} \\
\text { C. V. } \\
\text { Difference }(\%)\end{array}\right.$ & $\begin{array}{l}0.10_{3} \\
0.10_{4} \\
0.00_{6} \\
0.00_{3} \\
5.8 \\
\pm 0.00\end{array}$ & $\begin{array}{l}0.002_{8} \\
0.000_{8} \\
0.000_{4} \\
27.0 \\
-\end{array}$ & $\begin{array}{l}(0.003) \\
0.002_{3} \\
0.000_{8} \\
0.000_{3} \\
34.6 \\
-\end{array}$ & $\begin{array}{l}\overline{0.004_{0}} \\
0.001_{0} \\
0.000_{4} \\
26.0 \\
-\end{array}$ & $\begin{array}{l}\overline{0.003_{0}} \\
0.001_{0} \\
0.000_{3} \\
32.1 \\
-\end{array}$ & $\begin{array}{l}0.075 \\
0.076_{7} \\
0.005_{4} \\
0.002_{2} \\
7.0 \\
+0.002\end{array}$ & $\begin{array}{l}0.021 \\
0.019_{4} \\
0.002_{1} \\
0.001_{7} \\
10.8 \\
-0.002\end{array}$ & $\begin{array}{l}0.058 \\
0.058_{2} \\
0.002_{8} \\
0.002_{3} \\
4.8 \\
\pm 0.000\end{array}$ & $\begin{array}{l}\overline{0.002_{9}} \\
0.000_{9} \\
0.000_{4} \\
29.6 \\
-\end{array}$ & $\begin{array}{l}-\overline{0.003_{7}} \\
0.001_{0} \\
0.000_{5} \\
27.6 \\
-\end{array}$ & $\begin{array}{l}-\overline{0.003_{6}} \\
0.001_{1} \\
0.000_{5} \\
31.2 \\
-\end{array}$ \\
\hline $\mathrm{Pb}$ & $\left\{\begin{array}{l}\text { Certified value }(\%) \\
\text { Average }(\%) \\
\sigma_{\overline{\mathbf{x}}} \\
\sigma_{\mathrm{w}} \\
\text { C. V. } \\
\text { Difference }(\%)\end{array}\right.$ & $\begin{array}{l}0.022 \\
0.021_{6} \\
0.001_{6} \\
0.001_{0} \\
7.4 \\
\pm 0.000\end{array}$ & $\begin{array}{l}-\overline{0.002_{7}} \\
0.000_{8} \\
0.000_{5} \\
28.4 \\
-\end{array}$ & $\begin{array}{l}-\overline{0} 2_{4} \\
0.000_{9} \\
0.000_{2} \\
38.8 \\
-\end{array}$ & $\begin{array}{l}-\overline{0.002_{4}} \\
0.000_{7} \\
0.000_{4} \\
29.2 \\
-\end{array}$ & $\begin{array}{l}-\overline{0.002_{3}} \\
0.000_{8} \\
0.000_{6} \\
33.5 \\
-\end{array}$ & 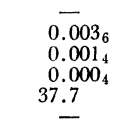 & $\begin{array}{l}-\overline{0.002_{5}} \\
0.000_{7} \\
0.000_{4} \\
27.8 \\
-\end{array}$ & $\begin{array}{l}-\overline{0.007_{7}} \\
0.000_{9} \\
0.000_{8} \\
12.2 \\
-\end{array}$ & $\begin{array}{l}-\overline{0.003_{2}} \\
0.001_{1} \\
0.000_{4} \\
34.7 \\
-\end{array}$ & $\begin{array}{l}\overline{0.003_{0}} \\
0.000_{8} \\
0.000_{5} \\
27.3 \\
-\end{array}$ & $\begin{array}{l}\overline{0.002_{6}} \\
0.000_{8} \\
0.000_{1} \\
30.6 \\
-\end{array}$ \\
\hline
\end{tabular}


共同実験は, 11 銘柄の共通試料について 試料の乾燥 から測定までの一連の操作を, 日を変えて独立に 2 回行 い，並行的に検量線の作成を行った。

実験に用いた試薬類については, アルカリ融解法に用 いた融解合剂以外は，JIS M 8204-1971 に規定された ものを用いた. 又, 実験に使用した原子吸光分析装置 は, Perkin Elmer 403 型, 同 107 型, 日本ジャーレ ル・アッシュ AA-70 型, 同 AA-1 型, 同 AA-780 型などであった. これらの装置を用いての分析条件は,

JIS M 8204-1971 に規定された方法に準じた.

実験期間は，試料が各分析室に到達した後，1 か月間 として分析データを 10 分析室から著者の下に回収し た.

\section{3 実 験 結果}

\section{1 酸分解法}

11 銘柄の共通試料について酸分解法で求めた 分析デ
一タを集咶し，成分ごとに総斗均 $[\bar{x}]$, 等間標準偏差 $\left[\sigma_{\overline{\mathrm{x}}}=\left\{\sum(\bar{x}-\bar{x})^{2} /(l-1)\right\}^{1 / 2}\right]$, 室内標準偏差 $\left[\sigma_{\mathrm{w}}=\bar{R} /\right.$ $\mathrm{d}_{2}$ ], 偏差率 $\left[\mathrm{C} . \mathrm{V} .=\left(\sigma_{\overline{\mathrm{x}}} / \overline{\bar{x}}\right) \times 100\right]$ 及び標準值との差を 求め, その結果を Table 2 に示した.

\section{2 アルカリ融解法}

$3 \cdot 1$ と同様にアルカリ融解法で求めた分析データを集 計して解析した結果を Table 3 に示した.

$$
4 \text { 考察 }
$$

二つの方法を評価するには，一般的に分析精度と正確 さを比較すればよい，分析精度は，共同実験の目的から 室間に打ける分析值の一致性を確認する意味で, 室間標 準偏差（ここでは $\sigma_{\overline{\mathrm{x}}}$ で表現した）を用いることにし， 更に各成分の含有率に忘じて一元的な分析精度で表現 するため直線回帰を行って分析精度と含有率との一次回 帰式を求めることにした．各成分ごとの一次回㷌式を

Table 3 Round robin test results of iron ores analysis by alkali-fusion A. A. S. method

\begin{tabular}{|c|c|c|c|c|c|c|c|c|c|c|c|c|}
\hline Element & & Rompin & Indian & Harmersley & Musan & Algarrobo & $\begin{array}{l}\text { Philippine } \\
\text { (Iron sand) }\end{array}$ & $\begin{array}{c}\text { Marcona } \\
\text { (Pellet) }\end{array}$ & Sinter & Chaugle & Dempo & $\begin{array}{c}\text { Mt. } \\
\text { Newman }\end{array}$ \\
\hline $\mathrm{Mn}$ & $\left\{\begin{array}{l}\text { Certified value }(\%) \\
\text { Average }(\%) \\
\sigma_{\overline{\mathrm{x}}} \\
\sigma_{\mathrm{w}} \\
\text { C. V. } \\
\text { Difference }(\%)\end{array}\right.$ & $\begin{array}{l}0.22 \\
0.23_{0} \\
0.00_{8} \\
0.00_{4} \\
3.5 \\
+0.01\end{array}$ & $\begin{array}{l}0.06 \\
0.06_{5} \\
0.00_{6} \\
0.00_{5} \\
9.2 \\
\pm 0.00\end{array}$ & $\begin{array}{l}0.09 \\
0.09_{0} \\
0.00_{6} \\
0.00_{3} \\
6.7 \\
\pm 0.00\end{array}$ & $\begin{array}{l}0.03 \\
0.03_{3} \\
0.00_{6} \\
0.00_{1} \\
18.2 \\
\pm 0.00\end{array}$ & $\begin{array}{l}0.05 \\
0.05_{5} \\
0.00_{7} \\
0.00_{2} \\
12.7 \\
+0.01\end{array}$ & $\begin{array}{l}0.61 \\
0.62_{2} \\
0.01_{3} \\
0.01_{3} \\
2.1 \\
+0.01\end{array}$ & $\begin{array}{l}0.04 \\
0.04_{1} \\
0.00_{3} \\
0.00_{1} \\
7.3 \\
\pm 0.00\end{array}$ & $\begin{array}{l}0.51 \\
0.51_{7} \\
0.02_{2} \\
0.00_{7} \\
4.3 \\
+0.01\end{array}$ & $\begin{array}{l}0 . \overline{49_{2}} \\
0.03_{4} \\
0.00_{9} \\
6.9 \\
-\end{array}$ & $\begin{array}{l}-\overline{5_{2}} \\
0.03_{6} \\
0.01_{6} \\
6.7 \\
-\end{array}$ & $\begin{array}{l}-\overline{0.07} \\
0.00_{5} \\
0.00_{3} \\
6.4 \\
-\end{array}$ \\
\hline $\mathrm{Cu}$ & $\left\{\begin{array}{l}\text { Certified value }(\%) \\
\text { Average }(\%) \\
\sigma_{\overrightarrow{\mathrm{x}}} \\
\sigma_{\mathrm{W}} \\
\text { C. V. } \\
\text { Difference }(\%)\end{array}\right.$ & $\begin{array}{c}0.065 \\
0.057_{0} \\
0.008_{0} \\
0.005_{3} \\
14.0 \\
-0.008\end{array}$ & $\begin{array}{c}(0.003) \\
0.003_{2} \\
0.001_{2} \\
0.000_{7} \\
38.2 \\
-\end{array}$ & $\begin{array}{l}(0.001) \\
0.002_{0} \\
0.001_{0} \\
0.000_{4} \\
48.5 \\
-\end{array}$ & $\begin{array}{l}(0.001) \\
0.001_{6} \\
0.000_{9} \\
0.000_{6} \\
53.1 \\
-\end{array}$ & $\begin{array}{c}0.012 \\
0.011_{1} \\
0.003_{6} \\
0.001_{6} \\
32.4 \\
-0.001\end{array}$ & $\begin{array}{l}0.011 \\
0.010_{2} \\
0.001_{7} \\
0.000_{8} \\
16.7 \\
-0.001\end{array}$ & $\begin{array}{l}0.015 \\
0.012_{9} \\
0.004_{8} \\
0.003_{9} \\
37.2 \\
-0.002\end{array}$ & $\begin{array}{l}0.018 \\
0.015_{8} \\
0.002_{5} \\
0.003_{2} \\
15.8 \\
-0.002\end{array}$ & $\begin{array}{l}0.002_{4} \\
0.0000_{7} \\
0.0000_{9} \\
28.3 \\
-\end{array}$ & $\begin{array}{l}-\overline{0.002_{4}} \\
0.001_{0} \\
0.001_{0} \\
39.7 \\
-\end{array}$ & $\begin{array}{l}-\overline{0.001_{8}} \\
0.000_{7} \\
0.0000_{5} \\
39.7 \\
-\end{array}$ \\
\hline $\mathrm{TiO}_{2}$ & $\left\{\begin{array}{l}\text { Certified value }(\%) \\
\text { Average }(\%) \\
\sigma_{\overline{\mathrm{x}}}^{\bar{x}} \\
\sigma_{\mathrm{w}} \\
\text { Ci. V. } \\
\text { Difference }(\%)\end{array}\right.$ & $\begin{array}{l}0.08 \\
0.07_{9} \\
0.00_{9} \\
0.00_{5} \\
11.0 \\
\pm 0.00\end{array}$ & $\begin{array}{l}0.16 \\
0.15_{6} \\
0.00_{8} \\
0.00_{3} \\
5.1 \\
\pm 0.00\end{array}$ & $\begin{array}{l}0.12 \\
0.11_{2} \\
0.00_{9} \\
0.00_{7} \\
8.0 \\
-0.01\end{array}$ & $\begin{array}{l}0.06 \\
0.05_{5} \\
0.00_{8} \\
0.00_{4} \\
13.9 \\
\pm 0.00\end{array}$ & $\begin{array}{l}0.22 \\
0.21_{1} \\
0.00_{9} \\
0.01_{0} \\
4.3 \\
-0.01\end{array}$ & $\begin{array}{l}6.33 \\
6.33_{3} \\
0.20_{5} \\
0.09_{9} \\
3.2 \\
\pm 0.00\end{array}$ & $\begin{array}{c}0.08 \\
0.07_{1} \\
0.00_{8} \\
0.00_{4} \\
11.5 \\
-0.01\end{array}$ & $\begin{array}{l}0.62 \\
0.59_{8} \\
0.02_{9} \\
0.02_{0} \\
4.8 \\
-0.02\end{array}$ & $\begin{array}{l}-\overline{0.10_{5}} \\
0.01_{2} \\
0.00_{5} \\
11.4 \\
-\end{array}$ & $\begin{array}{l}- \\
0.07_{2} \\
0.00_{8} \\
0.00_{6} \\
11.7 \\
-\end{array}$ & $\begin{array}{l}0.10_{7} \\
0.01_{2} \\
0.00_{6} \\
11.2 \\
-\end{array}$ \\
\hline $\mathrm{Ni}$ & $\left\{\begin{array}{l}\text { Certified value (\%) } \\
\text { Average }(\%) \\
\sigma \overline{\mathrm{x}} \\
\sigma_{\mathrm{w}} \\
\text { C. V. } \\
\text { Difference }(\%)\end{array}\right.$ & $\begin{array}{l}-\overline{0.002} \\
0.001_{2} \\
0.000_{4} \\
44.1 \\
-\end{array}$ & $\begin{array}{l}-\overline{0.004_{1}} \\
0.001_{0} \\
0.000_{8} \\
24.6 \\
-\end{array}$ & $\begin{array}{c}(0.003) \\
0.002_{9} \\
0.001_{2} \\
0.000_{6} \\
41.8 \\
-\end{array}$ & $\begin{array}{l}(0.002) \\
0.002_{5} \\
0.000_{8} \\
0.000_{3} \\
31.7 \\
-\end{array}$ & $\begin{array}{l}0.008 \\
0.007_{2} \\
0.001_{0} \\
0.000_{6} \\
14.6 \\
-0.001\end{array}$ & $\begin{array}{c}(0.006) \\
0.004_{6} \\
0.001_{0} \\
0.000_{5} \\
21.9 \\
-\end{array}$ & $\begin{array}{c}(0.006) \\
0.004_{8} \\
0.001_{8} \\
0.001_{2} \\
36.7 \\
\end{array}$ & $\begin{array}{l}0.012 \\
0.009_{7} \\
0.001_{8} \\
0.001_{4} \\
18.6 \\
-0.002\end{array}$ & $\begin{array}{l}-\overline{0.003_{3}} \\
0.0011_{4} \\
0.000)_{8} \\
43.4 \\
-\end{array}$ & $\begin{array}{l}- \\
0.002_{7} \\
0.001_{2} \\
0.0(0)_{6} \\
42.7 \\
-\end{array}$ & $\begin{array}{l}-\overline{0.002_{9}} \\
0.001_{4} \\
0.000_{6} \\
46.4 \\
-\end{array}$ \\
\hline $\mathrm{Cr}$ & $\left\{\begin{array}{l}\text { Certified value }(\%) \\
\text { Average }(\%) \\
\sigma_{\overline{\mathrm{x}}} \\
\sigma_{\mathrm{w}} \\
\text { C. V. } \\
\text { Difference }(\%)\end{array}\right.$ & $\begin{array}{l}-\overline{0.003_{2}} \\
0.001_{1} \\
0.000_{5} \\
35.8 \\
-\end{array}$ & $\begin{array}{l}0.012 \\
0.011_{4} \\
0.001_{0} \\
0.000_{6} \\
8.8 \\
-0.001\end{array}$ & $\begin{array}{l}(0.004) \\
0.002_{9} \\
0.001_{1} \\
0.000_{5} \\
38.2 \\
-\end{array}$ & $\begin{array}{l}(0.004) \\
0.003_{6} \\
0.001_{1} \\
0.000_{9} \\
29.4 \\
-\end{array}$ & $\begin{array}{c}(0.003) \\
0.001_{9} \\
0.000_{8} \\
0.000_{4} \\
41.0 \\
-\end{array}$ & $\begin{array}{l}0.018 \\
0.016_{5} \\
0.001_{9} \\
0.001_{0} \\
11.5 \\
-0.002\end{array}$ & $\begin{array}{l}(0.002) \\
0.001_{5} \\
0.000_{6} \\
0.000_{2} \\
44.5 \\
-\end{array}$ & $\begin{array}{l}0.023 \\
0.023_{6} \\
0.001_{2} \\
0.001_{2} \\
5.1 \\
\pm 0.001\end{array}$ & $\begin{array}{l}-\overline{0.003} \\
0.000_{9} \\
0.000_{3} \\
23.7 \\
-\end{array}$ & $\begin{array}{l}0.002_{7} \\
0.001_{0} \\
0.000_{3} \\
35.7 \\
-\end{array}$ & $\begin{array}{l}-\overline{0.003_{9}} \\
0.001_{0} \\
0.000_{6} \\
25.8 \\
-\end{array}$ \\
\hline V & $\left\{\begin{array}{l}\text { Certified value }(\%) \\
\text { Average }(\%) \\
\sigma_{\overline{\mathrm{x}}} \\
\sigma_{\mathrm{w}} \\
\text { C. V. } \\
\text { Difference }(\%)\end{array}\right.$ & $\begin{array}{l}0.006 \\
0.005_{4} \\
0.000_{8} \\
0.000_{6} \\
15.2 \\
-0.001\end{array}$ & $\begin{array}{l}0.008 \\
0.007_{1} \\
0.001_{1} \\
0.000_{5} \\
15.3 \\
-0.001\end{array}$ & $\begin{array}{c}(0.003) \\
0.003_{3} \\
0.001_{4} \\
0.000_{4} \\
41.9 \\
-\end{array}$ & $\begin{array}{l}0.003 \\
0.003_{2} \\
0.001_{1} \\
0.000_{6} \\
33.0 \\
\pm 0.000\end{array}$ & $\begin{array}{l}0.16 \\
0.16_{1} \\
0.01_{2} \\
0.00_{6} \\
7.5 \\
\pm 0.00\end{array}$ & $\begin{array}{l}0.30 \\
0.30_{8} \\
0.01_{0} \\
0.01_{2} \\
3.2 \\
+0.01\end{array}$ & $\begin{array}{l}0.049 \\
0.051_{0} \\
0.004_{8} \\
0.002_{0} \\
9.4 \\
+0.002\end{array}$ & $\begin{array}{l}0.040 \\
0.039_{8} \\
0.002_{4} \\
0.001_{1} \\
6.2 \\
\pm 0.000\end{array}$ & $\begin{array}{l}-\overline{0.002_{5}} \\
0.001_{0} \\
0.000_{4} \\
39.9 \\
-\end{array}$ & $\begin{array}{l}-\overline{0.002_{5}} \\
0.0000_{7} \\
0.000_{4} \\
29.7 \\
-\end{array}$ & $\begin{array}{l}-\overline{0.002_{6}} \\
0.000_{8} \\
0.000_{8} \\
31.1 \\
-\end{array}$ \\
\hline $\mathrm{Zn}$ & $\begin{array}{l}\text { Certified value }(\%) \\
\text { Average }(\%) \\
\sigma \overline{\mathrm{x}} \\
\sigma_{\mathrm{w}} \\
\text { C. V. } \\
\text { Difference }(\%) \\
\text { Certified value }(\%)\end{array}$ & $\begin{array}{l}0.10_{3} \\
0.10_{5} \\
0.00_{5} \\
0.00_{2} \\
4.8 \\
\pm 0.00 \\
0.022\end{array}$ & $\begin{array}{l}-\overline{0.003_{0}} \\
0.001_{3} \\
0.000_{9} \\
42.4 \\
-\end{array}$ & $\begin{array}{c}(0.003) \\
0.001_{9} \\
0.000_{8} \\
0.000_{3} \\
43.6 \\
- \\
-\end{array}$ & $\begin{array}{l}-\overline{0} \\
0.004_{3} \\
0.001_{4} \\
0.000_{4} \\
32.9 \\
-\end{array}$ & $\begin{array}{l}-\overline{0.002_{2}} \\
0.000_{6} \\
0.000_{5} \\
28.1 \\
-\end{array}$ & $\begin{array}{l}0.075 \\
0.078_{8} \\
0.008_{2} \\
0.001_{7} \\
10.4 \\
+0.004 \\
-\end{array}$ & $\begin{array}{c}0.021_{1} \\
0.018_{5} \\
0.002_{1} \\
0.001_{4} \\
11.4 \\
-0.003\end{array}$ & $\begin{array}{l}0.058 \\
0.057_{6} \\
0.001_{7} \\
0.002_{2} \\
3.0 \\
\pm 0.000\end{array}$ & $\begin{array}{l}-\overline{0} \\
0.002_{3} \\
0.000_{8} \\
0.000_{6} \\
35.4 \\
-\end{array}$ & $\begin{array}{l}-\overline{0.003_{2}} \\
0.001_{2} \\
0.000_{8} \\
37.1 \\
- \\
-\end{array}$ & $\begin{array}{l}-\overline{0} \\
0.003_{4} \\
0.001_{6} \\
0.001_{0} \\
47.5 \\
- \\
-\end{array}$ \\
\hline $\mathrm{Pb}$ & $\left\{\begin{array}{l}\text { Certified value }(\%) \\
\text { Average }(\%) \\
\sigma \overline{\mathrm{x}} \\
\sigma_{\mathrm{w}} \\
\text { C. V. } \\
\text { Difference }(\%)\end{array}\right.$ & $\begin{array}{l}0.022 \\
0.016_{3} \\
0.006_{1} \\
0.000_{6} \\
37.4 \\
-0.006\end{array}$ & $\begin{array}{l}-\overline{0.002_{6}} \\
0.001_{2} \\
0.000_{6} \\
47.7 \\
-\end{array}$ & $\begin{array}{l}-\overline{0.002_{4}} \\
0.000_{7} \\
0.000_{6} \\
37.3 \\
-\end{array}$ & $\begin{array}{l}-\overline{0.002_{6}} \\
0.001_{1} \\
0.000_{6} \\
43.9 \\
-\end{array}$ & $\begin{array}{l}-\overline{0.002_{2}} \\
0.001_{1} \\
0.000_{4} \\
49.5 \\
-\end{array}$ & $\begin{array}{l}-\overline{0.003_{4}} \\
0.001_{5} \\
0.000_{4} \\
44.2 \\
-\end{array}$ & $\begin{array}{l}-\overline{0.002_{4}} \\
0.001_{3} \\
0.000_{9} \\
52.2 \\
-\end{array}$ & $\begin{array}{l}\overline{0.006_{0}} \\
0.002_{3} \\
0.000_{6} \\
38.5 \\
-\end{array}$ & $\begin{array}{l}-\overline{0.002_{4}} \\
0.001_{2} \\
0.000_{8} \\
50.0 \\
-\end{array}$ & $\begin{array}{l}0.002_{8} \\
0.001_{4} \\
0.000_{8} \\
48.4 \\
-\end{array}$ & $\begin{array}{c}\overline{0.002_{6}} \\
0.000_{8} \\
0.000_{9} \\
33.2 \\
-\end{array}$ \\
\hline
\end{tabular}


Table 4 Analytical precision of trace elements in iron ores obtained from this work

\begin{tabular}{|c|c|c|c|c|}
\hline \multirow{2}{*}{ Element } & \multicolumn{2}{|c|}{ Acid-attack method } & \multicolumn{2}{|c|}{ Alkali-fusion method } \\
\hline & Regression equation & $r \dagger$ & Regression equation & $r \dagger$ \\
\hline Mangnaese & $\sigma_{\overline{\mathrm{x}}}=0.0258 \mathrm{Mn}(\%)+0.0028$ & 0.946 & $\sigma \overrightarrow{\mathrm{x}}=0.0395 \mathrm{Mn}(\%)+0.0033$ & 0.800 \\
\hline Copper & $\sigma \overline{\mathrm{s}}=0.0164 \mathrm{Cu}(\%)+0.00044$ & 0.866 & $\sigma_{\overline{\mathrm{x}}}=0.131 \mathrm{Cu}(\%)+0.00094$ & 0.924 \\
\hline Titanium oxide & $\sigma \overline{\mathrm{x}}=0.0612 \mathrm{TiO}_{2}(\%)+0.0021$ & 0.976 & $\sigma \overline{\mathrm{x}}=0.0373 \mathrm{TiO}_{2}(\%)+0.0054$ & 0.938 \\
\hline Nickel & $\sigma \overrightarrow{\mathrm{x}}=0.0624 \mathrm{Ni}(\%)+0.0012$ & 0.420 & $\sigma \overline{\mathrm{x}}=0.0620 \mathrm{Ni}(\%)+0.0010$ & 0.433 \\
\hline Chromium & $\sigma \overrightarrow{\mathrm{x}} \quad 0.0565 \operatorname{Cr}(\%)+0.00034$ & 0.904 & $\sigma_{\bar{x}}=0.0276 \operatorname{Cr}(\%)+0.00088$ & 0.617 \\
\hline Vanadium & $\sigma \overline{\mathrm{x}} 0.0815 \mathrm{~V}(\%)-0.0022$ & 0.943 & $\sigma \overline{\mathrm{x}}=0.0368 \mathrm{~V}(\%)+0.0013$ & 0.887 \\
\hline Zinc & $\sigma \overline{\mathrm{x}}=0.0508 \mathrm{Zn}(\%)+0.0008$ & 0.978 & $\sigma \overline{\mathrm{x}}=0.0508 \mathrm{Zn}(\%)+0.0010$ & 0.818 \\
\hline Lead & $\sigma \overline{\mathrm{x}}=0.0015 \mathrm{~Pb}(\%)+0.0009$ & 0.542 & $\sigma \overline{\mathrm{x}}=0.359 \mathrm{~Pb}(\%)+0.0002$ & 0.994 \\
\hline
\end{tabular}

$\dagger r$ : Coefficient of correlation between $\sigma \overline{\mathrm{x}}$ and contents $(\%) ; \quad \sigma \overline{\mathrm{x}}:$ Standard deviation between laboratories

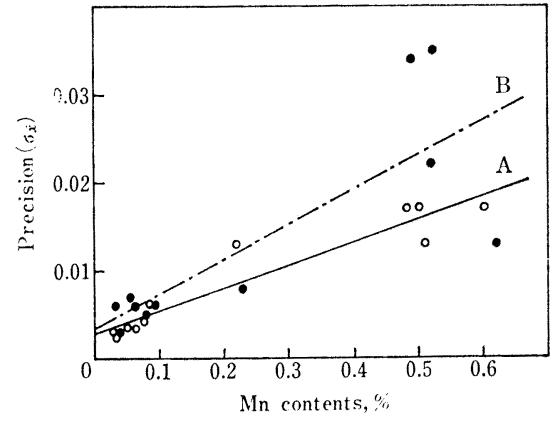

Fig. 1 Precision of manganese determination

$\Lambda$ : Acid-attack $\Lambda$. A. S. method, $\sigma \overline{\mathrm{X}}=0.0258 \mathrm{Mn}(\%)$ $+0.0028 ; \quad B:$ Alkali-fusion A.. S. methorl, $\sigma \overline{\mathrm{X}}-$ $0.0395 \mathrm{Mn}(\%)+0.0033$

Table 4 に示した. 又，一次回㷌式と各点の分布との関 係をマンガンの場合について Fig. 1 に示した.

正確さは，用いた共通試料で，日本鉄鋼標準試料の場 合は標準值が表示されているので，その標準值との差を 求めて比較した。しかし，一般に特殊な微量成分は，標 準值の表示がないので，このような場合は，酸分解法の 值を標準とした。ここでも標準値との差の有意性を実験 した含有率の範囲内で平均的に求めるために標準值ある いは酸分解法で求めた值とアルカリ融解法で求めた值と の差を含有率に対して求めることにした. その1例をマ ンガンの場合について図示したものが Fig. 2 である.

又, この実験では, 比較的微量域での定量を行ってい ることから検出下限や定量下限を推定することも可能で ある. 検出下限や定量下限の求め方については種々の見 解があるが，ここでは偏差率から推定してみることにす る.

まず検出下限は, 偏差率 $30 \%$ に相当する目的元素含 有率とする，その理由は，偏差率 $30 \%$ を持つデータ群 中には $3 \sigma$ 管理限界 $(99.7 \%)$ を考えた場合，各分析室 のデータ（2回分析の平均值）には偏差率 $90 \%$ にも相

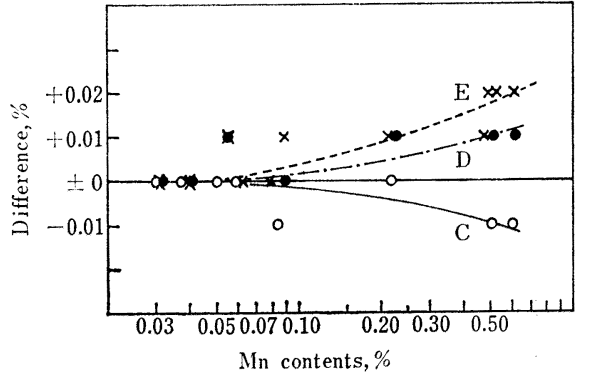

Fig. 2 Accuracy of manganese determination

$\mathrm{C}:[$ Average of acid-attack method]-[Certified value]; $\mathrm{D}:$ [Average of alkali-fusion method]-[Certified value $]$; $\mathrm{E}:$ [Average of alkali-fusion method] $-[$ Average of acidattack method]

当する值が含まれているはずである，換言すれば，正側 のデータでは約 2 倍の值が，負側のデータでは負にはな らないが 0 に近い值が存在することになる。つまり負側 のデータに注目すれば全参加分析室で検出される最小量 （検出下限）といらことになる.

次に定量下限は, 偏差率 $10 \%$ に相当する目的元素含 有率とする. その理由は次のとおりである.

JIS Z 8402-1974 (分析·試験の許容差通則) 付属書 4 に示されている Pearson, Stephens の方法を用いて最 大值と最小值の両者を同時に検定するときの棄却限界を 求めてみると危険率 $1 \%(l=10)$ で $R=3.875 \sigma_{\bar{x}}$ とな る. ここで $R$ は最大值と最小值の範囲であるので, 平均 值に対する許容されるばらつきは， $\pm 1.94 \sigma \overline{\mathbf{x}} \fallingdotseq \pm 2 \sigma_{\overline{\mathbf{x}}}$ と なる、ここで例えば含有率 $0.01 \%$ における偏差率を $10 \%$ とすると許容されるばらつきは $\pm 0.002 \%$ となり， 定量分析上技術的に常識的な值となる. 従って, 偏差率 $10 \%$ に相当する目的元素含有率を定量下限とした.

偏差率と目的元素含有率との関係の例をマンガン及び 銅について図示すると Fig. 3 のとおりである.このよ らな関係図を各成分について作図して上述した検出下限 及び定量下限を求めて Table 5 に示した. なお Table 
Table 5 Detection and determination limits obtained from the round robin test on analysis of iron ores by A. A. S. method

\begin{tabular}{|c|c|c|c|c|c|}
\hline \multirow[b]{2}{*}{ Element } & \multicolumn{2}{|c|}{ Detection limit (\%) } & \multicolumn{2}{|c|}{ Determination limit (\%) } & \multirow{2}{*}{$\begin{array}{c}\text { JIS M8204-1971 } \\
\text { application } \\
\text { lower limit } \\
(\%)\end{array}$} \\
\hline & $\begin{array}{l}\text { Acid-attack } \\
\text { method }\end{array}$ & $\begin{array}{l}\text { Alkali fusion } \\
\text { method }\end{array}$ & $\begin{array}{l}\text { Acid-attack } \\
\text { method }\end{array}$ & $\begin{array}{l}\text { Alkali-fusion } \\
\text { mcthod }\end{array}$ & \\
\hline Manganest: & $0.008 \uparrow$ & $0.02 \dagger$ & 0.0 .3 & 0.0 .5 & 0.01 \\
\hline Copper & 0.0015 & 0.004 & 0.005 & -.. & $0.0(0) 1$ \\
\hline Titanium oxide & 0.02 & $0.02 \dagger$ & 0.09 & 0.09 & $0.1017+t$ \\
\hline Nickel & 0.005 & 0.001 & $0.02+$ & $10.02+$ & $0 .(x) 1$ \\
\hline Chromium & 0.002 & 0.003 & 0.0606 & 0.01 & 0.0011 \\
\hline Vanadium & 0.003 & 0.003 & 0.01 & 0.01 & $0.0(0) 1$ \\
\hline Zinc & 0.003 & 0.004 & 0.01 & 0.01 & 0.001 \\
\hline Lead & 0.003 & - & 0.01 & - & 0.001 \\
\hline
\end{tabular}

$\dagger$ Point on the extension of the line; †† Corresponding with $0.01 \%$ as $\mathrm{Ti}$

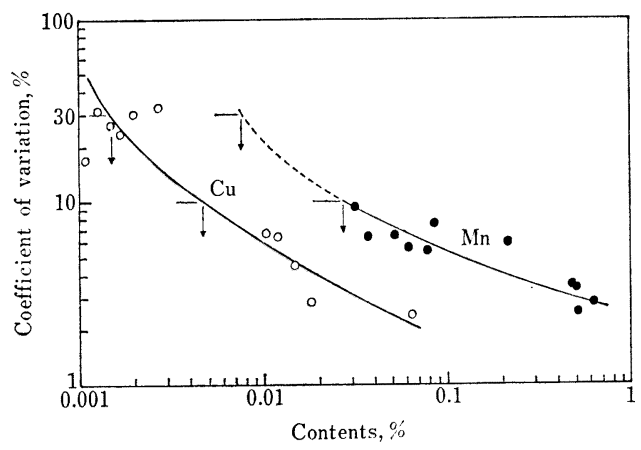

Fig. 3 Goefficient of variation vs. element contents in iron ores by acid-attack A. A. S. method

5 中で†印の数值は, 延長線上から求めた值である.

一方，JIS M 8204-1971 に示されている適用下限と Table 5 中の值を比較してみると，JIS の適用下限はい ずれもこの実験結果の検出下限に近似の值であることが 分かる.

以上の分析精度, 正確さ, 検出下限及び定量下限につ いて両分解方法を比較しながら各成分ごとに考察した結 果を以下に述べる.

(1) マンガン マンガン含有率 $0.1 \%$ 以上では, 酸分解法が負側, アルカリ融解法が正側の傾向を示した が，この傾向もマンガン含有率 $0.60 \%$ に拈いて平均值 間には危険率 $5 \%$ で有意差はなかった.

（2）銅 アルカリ融解法の分析精度が非常に悪 く, 正確さでも銅含有率 $0.01 \%$ 以上では負の偏りを持 っていた．この原因は，アルカリ融解法では試料を直接 白金るつぼで融解するため，融解時に試料中の銅が白金 と合金を生成して損失を招くものと考えられる.これに 対して, 酸分解法では試料中の銅は酸分解主液中に移行 してしまうため，白金るつぼを使用して残さ処理を行っ ても合金生成による損失はほとんどないものと考光られ
る.

アルカリ融解法の定量下限は，実験範囲内で偏差率が すべて 10\% 以上であったため求めることができなかっ た. 従って，鉄鉱石中の銅定量には，アルカリ融解法は 適用できないことになる。

（3）酸化チタン チタンのみは，鉄鋼業界の慣例 に従って元素表示でなく酸化物表示とした.

分析精度及び正確さともに酸化チタン含有率 $0.2 \%$

以上では両分解法間に比較的大きな差があり, 酸分解法 では負の偏りとなった。

この原因は，酸分解法（JIS M 8204-1971）に上ると きは，チタン含有率が高くなると試料溶液中の塧酸濃度 が低いのでヂンが加水分解しやすくなることによると 考えられる.すなわち，酸化チタンの定量精度及び正確 さを向上させるには，次のような酸分解法を行う必要が ある。

$2 \cdot 3 \cdot 1$ (1) i ) で得た乾固物を冷却後, 更に塩酸 10 $\mathrm{ml}$ を加えて塩類を溶解した後, 塩酸 $(1+10)$ を加えて 液量を約 $30 \mathrm{ml}$ とし, 万紙 (5 種 B) を用いて不溶解残 さをろ過する．万紙及び残さを塩酸 $(1+10)$ を用いて 洗液に鉄イオンが認められなくなるまで洗浄する．万洗 液は主液として保存する. 残さはろ紙とともに白金るつ ぼに移し入れて灰化し, 常法により二酸化ケイ素分を揮 散させ，ピ口硫酸カリウム約 $2 \mathrm{~g}$ を加えて融解する. 冷 却後融成物を主液に溶解して $100 \mathrm{ml}$ のメスフラスコに 移し入れ，アルミニウム溶液 $(5 \mathrm{mgAl} / \mathrm{ml}) 10 \mathrm{ml}$ を加 光て塩酸 $(1+10)$ で標線までうすめる.

（4）ニッケル 両分解方法とも分析精度はほとん ど同程度であったが正確さは，ニッケル含有率 $0.005 \%$ 以上に敃いてアルカリ融解法のほらがやや低值を示す傾 向にあった。

この原因は, アルカリ融解法の場合, 融解時にニッケ ルが白金と合金を生成して損失することも考えられる 
が，今回実験に供した試料中のニッケルの最大含有率が $0.01 \%$ 程度であり，しかもその付近に打ける偏差率が 両分解方法とも約 $15 \%$ もあることから両者間に有意な 差があるとは判断できなかった。もしろニッケルの微量 域での定量には鉄のバックグラウンド吸光の補正が必要 であるので, バックグラウンド吸光補正用鉄溶液の調製 方法に問題があったと考えるべきである，今回の実験で は，バックグラウンド吸光補正用鉄溶液の調製には JSS 802 (酸化鉄) を用いた。この酸化鉄中には $(0.003$

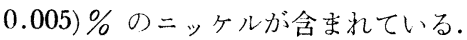

一般に，我が国で使用している原料鉄鉣石中に含有さ れるニッケル量が $0.01 \%$ をこすことはごくまれである つで，JIS M 8204 に規定されている原子吸光法の感度 问上対策が必要である.

（5）クロム アルカリ融解法の分析精度が，ク口 厶含有率 $0.005 \%$ 以下で若干悪い傾向にあるが，F 検 定（两側 5\%) の結果では有意な差ではなかった，正確 さについても両分解法間に有意な差はなかった。しか し，JIS M 8204 に規菦されている酸分解法でもその定 星卜限唯 $0.006 \%$ であり，一般に我が国で使用してい る原料鉄鉱石中のクロム含有疽がそれ以上であることが まれであることから，微量域での分析条件については舴 検討が必要である.

(6) バナジゥム帑分解法に扣ける回帰值線のこ ら配が高かったのは，つィリッピン砂鉄試料の室間標準 偏差が異常に宲いためである。この理由は，酸化チタン の項で述べたように JIS M 8204 法での試料溶液の酸 濃度が低すぎるためチタンが加水分解を起こしやすい状 態になっているためバナジウムの定量にも悪影響を与え たものと考えられる. 従って, 酸分解法でのバナジウム の分析精度を问上させるには, 酸化チタンの項で述べた よらな試料浴液の調製力法を採用すれはばよい。

我が国で使用している原料鉄鉣不中のバナジゥム含有 率は，砂鉄を除いて $0.1 \%$ をこすことはまれであるが， 鉄鉱石中の全鉄を定量する際に悪影響を及ぼす成分であ るため分析ひん度も多く, 正確さも要求される. 今回の 実験結果からでは，両分解法とも定量下限が $0.01 \%$ で あり，JIS M 8204-1971 に示されている適用下限 0.001 \% とは大きな差があった。

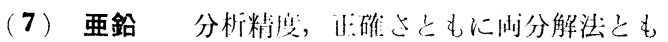
全く问一とみてよい。

鉄鉱石中の亜鉛は，高炉操業に悪影響を与える成分で あるので，上り低含有率であることが望まれる。この 春験で求わた定鼠下限 $0.01 \%$ は満足できるぬのではな い. バナジウムと同様 JIS M 8204-1971 に示されてい
万滴用下限 $0.001 \%$ とは大きな差があった。

(8) 鉛 分析精度, 正確さともに雨分解法間で大 きな妻があった。

この原因は，アルカリ融解法では，銅の場合と同様に 試料の融解時に白金と鉛が合金を生成して損失するもの と考えられる，従って，鉛含有率 $0.005 \%$ 以上の試料 にはアルカリ融解法は適用できない.

鉄鉱石中の鉛は，亜鉛と同様に高炉操業に悪影響を与 える成分であるのでより低含有率であることが望まれ， 通常の鉄鉣石中には $0.01 \%$ 以上含有することはごくま れである. 従って，この実験から求めた定量下限 0.01 \%は満足できるものではない.

$$
5 \text { あとがき }
$$

11 銘枘の 鉄鉣石を選び，その中のマンガン，銅，酸 化チタン，ニッケル，クロム，バナジウム，亜鉛及び鉛 の 8 成分を JIS M 8204 に規定されている酸分解法と 省力化を考慮したアルカリ融解法の 2 方法を用いて社内 10 分析室で共同実験し，得られた結果を解析して両分 解法の分析精度と正確さを比較した. 又, 偏差率から検 出下限（偏差率 $30 \%$ に相当する目的元素含有率）と定 量下限 (偏差率 $10 \%$ に相当する目的元素含有率)を求 めて鉄鉱石分析一の適用性を論じた. その結果をとりま とめると次のと打りである。

\section{（1）JIS M 8204-1971 法（酸分解法）}

i ) 酸化チタン及びバナジウムを除いた他の成分の分 析精度及び正確さは，アルカリ融解法に比べて同等かあ るいは優れている。

ii ）高含有率酸化チタンの定量には, 試料溶液中の暏 酸濃度を上げる必要がある。

iii）酸化チタン高含有試料中のバナジウムの定量の場 合も同様である.

iv）全般的に JIS M 8204-1971 に示されている適用 下限は，この実験結果から求めた検出下限に近似した值 である。

\section{（2）アルカリ融解法}

i ）分析精度及び正確さは，酸化チタン及びバナジウ ムについては酸分解法より優れ，マンガン，ニッケル， クロム，西鉛については同程度で，銅及び鉛については 代过で女った。特に銅及び鉛の定量には，アルカリ融解 法の徳用には綮しい制限が必要である。

ii）検出下限及び定量下限は，銅及び鉛を除いて酸分 解法と同程度である。

これらの結果から鉄鉱石中の微量成分定量の省力化の ためには，銅及び鉛の定量を除いてアルカリ融解法は有 
効な方法であった。

終わりに，アルカリ融解法を提案した広畑製鉄所技術 管理部分析課長佐伯正夫氏及びこの共同実験に参加した 各分析室の分析者諸氏に感謝の意を表する.

象

A round robin test on the determination of traces of metals in iron ores by atomic absorption spectrophotometry; With special reference to the open-up of samples with acid attack and alkali fusion. Takashi OTSUKI (Fundamental Research Laboratories, Nippon Steel Corporation, 1618, Ida, Nakahara-ku, Kawasaki-shi, Kanagawa)

Interlaboratory tests were conducted to ascertain a good open-up method for the determination of traces of manganese, copper, titanium, nickel, chromium, vanadium, zinc and lead in iron ores by atomic absorption spectrophotometry. The test were cooperated by ten laboratories within the Nippon Steel Corp., placing a special attention on two open-up methods, acid attack and alkali fusion. The two methods were compared from one another with respect to precision and accuracy for each metal. Discussion was also given for the detection limits and lower limits of determination. Based on these observations the open- up with hydrochloric acid turned out to give accurate results for the analysis of standard iron ores. Precision was also quite satisfactory. However, it was recommended to increase the hydrochloric acid concentration of test solutions for the determination of titanium and vanadium. The alkali fusion yielded the lower results for lead and copper, presumably because of the formation of their alloys with platinum crucible during the fusion process. However, the results for manganese, titanium, nickel, chromium, vanadium and zinc were in good agreement with their certified values for standard iron ores. The precision for each metal was also satisfactory. Analytical precision was found to be quite low at the lowest limit of concentration for the method described in JIS M 8204-1971, exceeding $30 \%$ in the coefficient of variation.

(Received Sept. 14, 1978)

\section{Keywords}

Atomic absorption spectroscopy

Decomposition

Iron ores

Trace elements

\title{
フッ化物沈殿分離-酸化物ひょう量形とする 希土類元素重量分析法の問題点
}

\author{
高田九二雄*
}

(1978 年 8 月 3 日受理)

\begin{abstract}
希土類元素のフッ化物沈殿を都市ガス炎で強熱し酸化物として重量分析すると, 軽希土類元素では (4〜7)％高い分析值が得られた。これは，フッ化物が強熱で十分に酸化されずオキシフルオリド ( $\mathrm{LnOF})$ が生成し，一部生成した酸化物と混在するためであった。フッ化ランタンは都市ガス炎による 強熱を繰り返しても化学量論的な酸化物 $\left(\mathrm{La}_{2} \mathrm{O}_{3}\right)$ にならなかった。つまり, フッ化物恃重量分析のた めの沈殿として不適当であった。このため，希土類元素の分析のために，フッ化物沈殿を強热後酸溶解 し，EDTA 滴定する方法を行った。
\end{abstract}

\section{1 緒言}

電子，磁性及び耐熱材料として 1 種類の希土類元素を 含む合金, セラミックスが近年研究されたり実用化され

\footnotetext{
* 東北大学金属材料研究所 : 宮城県仙台市片平 2-1-1
}

たりしている.このよらな材料中の希上類元素の分析 法として沈殿分離重量法がある. 沈殿分離法としては フッ化物1) 4), 水酸化物 ${ }^{3(5)}$, 無機複塩14)677), シュウ酸 塩3) 5), 有機試薬との錯盐8) 10) などの方法がある.こ れらの方法のらちで，フッ化物法が沈殿条件の規定がし 